\title{
Study of ocular aberrations with age
}

\author{
Estudo das aberrações oculares e idade
}

\author{
Helaine Vinche Zampar Athaide ${ }^{1}$ \\ MauroCampos $^{2}$ \\ Charles Costa ${ }^{3}$
}

\begin{tabular}{|c|}
\hline ABSTRACT \\
\hline 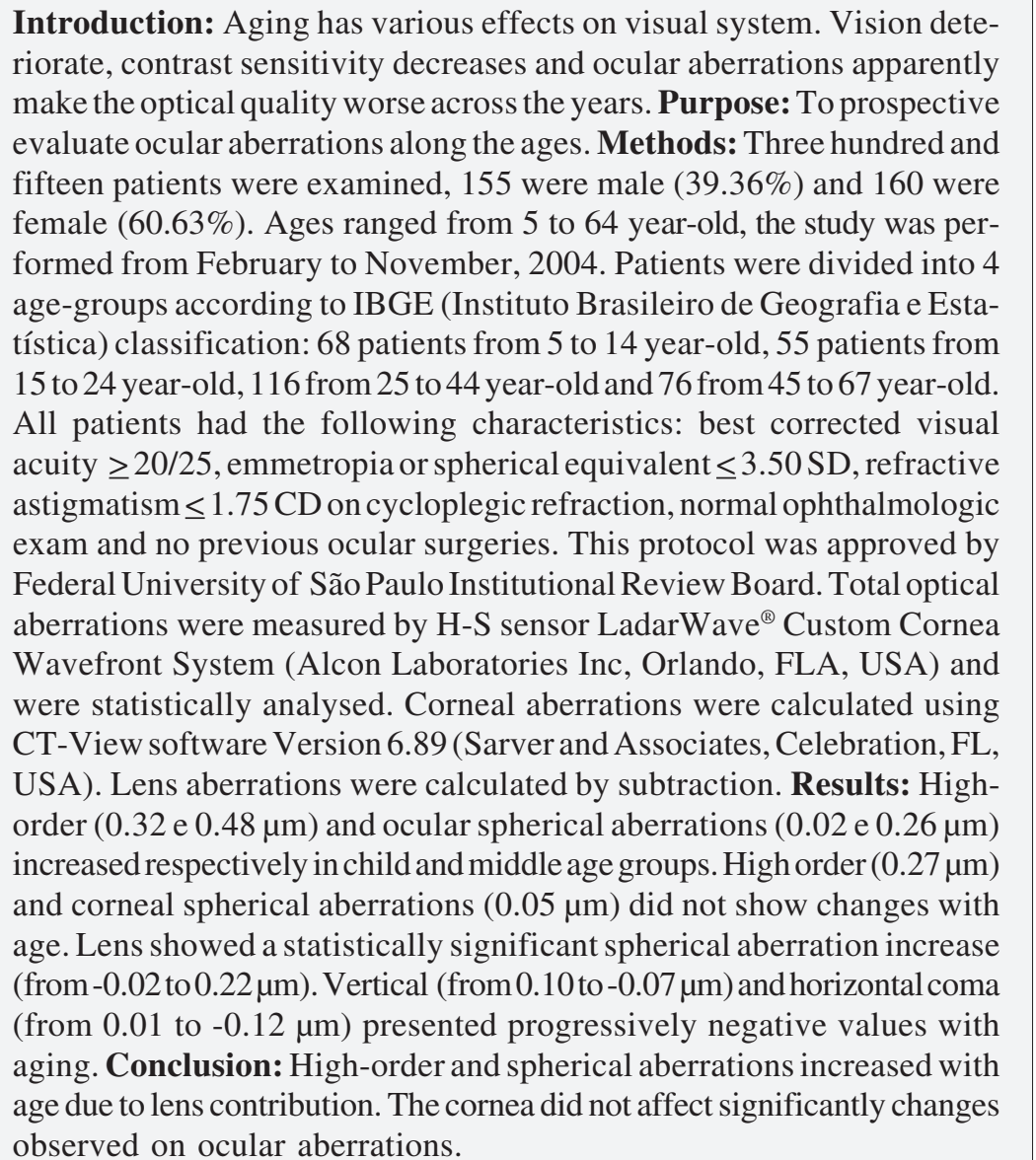 \\
\hline
\end{tabular}

Keywords: Ocular physiological phenomena; Corneal topography; Aging/physiology; Refractive errors/physiopathology; Refraction, ocular/physiology; Diagnostic technique, opthalmologic; Visual acuity/physiology; Lens, crystalline/physiology da Universidade Federal de São Paulo - UNIFESP - São Paulo (SP) - Brazil.

${ }^{1}$ Doutorado na área de Cirurgia Refrativa da Universidade Federal de São Paulo - UNIFESP - São Paulo (SP) Brazil.

${ }^{2}$ Professor Doutor da UNIFESP - São Paulo (SP) - Brazil.

${ }^{3}$ Médico colaborador no Setor de Córnea e Cirurgia Refrativa da UNIFESP - São Paulo (SP) - Brazil.

Correspondence address: Helaine Vinche Zampar Athaíde. Rua Martiniano de Carvalho, 836 - Apto. 272 Bloco 2 - São Paulo (SP) CEP 01321-000

E-mail: helaine_zampar@hotmail.com

Recebido para publicação em 09.03.2009

Última versão recebida em 12.08.2009

Aprovação em 03.09.2009

Nota Editorial: Depois de concluída a análise do artigo sob sigilo editorial e com a anuência do Dr. José Américo Bonatti sobre a divulgação de seu nome como revisor, agradecemos sua participação neste processo.
Aging has various effects on visual system. Age-related visual deterioration can be due to both neural and optical factors, but its relative contribution remains uncertain. Elderly have lower contrast sensitivity due to higher light scatter, and ocular aberrations seem to increase with age, this is one reason for the lower visual quality in older adults ${ }^{(1)}$.

In the present study, the relation between ocular, lens and corneal aberrations with age were investigated in patients without ocular diseases except lower ametropia. To obtain information about changes in optical properties along the age, it is important to study a large number of patients, including

\section{INTRODUCTION}


children. Literature reports similar studies but none studied agegroups from 5 to 64 year-old.

Moreover, ocular aberration knowledge can facilitate the development of new techniques to minimize age-related visual impairment and help physicians to inform better the patients about potential changes in postoperative ocular results with aging ${ }^{(2)}$.

\section{METHODS}

\section{Sample selection}

A total of 630 eyes of 315 patients, 155 (49\%) male, 160 female (51\%); mean age of 31 years $( \pm 16.03$; range 5-64 years) were evaluated. All subjects or their parents provided informed consent, and the study was conducted according to the tenets of Declaration of Helsinki. Subjects came spontaneously for consultation and exams. The subjects were subdivided into four age-groups according to the guidelines of Geography and Statistical National Institute (IBGE - www. ibge.com.br): children ( $n=68 ; 5=14$ year-old), young adults $(\mathrm{n}=55 ; 15-24$ year-old $)$, adults $(\mathrm{n}=116 ; 25-44$ year-old $)$, and middle aged adults ( $\mathrm{n}=76 ; 45-64$ year-old). The subjects were submitted to ophthalmic examination in the Department of Refractive Surgery of the Federal University of São Paulo from February to November 2004.

\section{Ocular examination}

All ocular examination were performed by the same ophthalmologist. None of the subjects had any ocular disease other than mild refractive errors, such as myopia, hyperopia (spherical equivalent $\leq 3.50 \mathrm{SD}$ ) and regular forms of astigmatism $(\leq 1.75 \mathrm{CD} \text { refractive cylinder in diopters })^{(3)}$. Exclusion criteria were best corrected visual acuity $\leq 20 / 25$, dry eye, previous ocular surgery, irregular astigmatism or inferior asymmetry in the topography, contact lens users, history and presence of cataracts or other ocular opacities and systemic diseases. The Lens Opacities Classification System III was used to assess lens transparency. Only clear lens were accepted.

Complete ocular exam included measurement of the best corrected visual acuity and cycloplegic refraction using 2 drops of $1 \%$ cyclopentolate with a 40-minute delay between drops instillation and testing. Anterior segment biomicroscopy and fundoscopy were also performed. Patients were screened for dry eye considering qualitative evaluation of lacrimal meniscus, $1 \%$ fluorescein BUT and presence of surface staining. Inferior asymmetry of corneal topography when identified was excluded ${ }^{(3)}$.

Ocular wavefront aberrations were calculated from images recorded with a Hartmann-Shack (H-S) sensor. LADARWave ${ }^{\circledR}$ (Custom Cornea Wavefront System, Alcon Laboratories Inc, Orlando, Fl) was used, which provided five ocular aberrometry measurements and calculated the aberration using the best three measurements.

Corneal aberrations were calculated using a VOL-CT software, version 6.89 (Sarver and Associates, Celebration, FL).
This software analyzes anterior elevations corneal data and calculates corneal aberrations by ray tracing.

Anterior corneal elevations data were obtained using an Orbscan II (Bausch\&Lomb, Orbtek Inc, Salt Lake City, UT).

Lens aberrations were calculated by subtraction from ocular and corneal data for every subject before statistical analysis.

Aberrations were calculated for a $6.5-\mathrm{mm}$ pupil using (up to $6^{\text {th }}$ order) Zernike coefficients. All exams were centered at the pupil entrance.

\section{Statistical analysis}

Descriptive data included median, minimum, and maximum values. Data normality were evaluated using the Kolmogorov-Smirnov and Shapiro-Wilk tests. Because variables did not pass normality tests, a Kruskal Wallis non-parametric test was used. It was applied separately for each aberration in the right and left eyes to test differences between age-groups. The Dunn test was used to complement the analysis among age-groups.

Spearman's rank coefficient (r) was also used to correlate ordinal variables. A $p$ value of 0.05 or less was considered to be statistically significant.

Symmetry between aberrations and eyes was evaluated with a two-way analysis of variance (ANOVA test).

\section{RESULTS}

\section{Comparison of right and left eye aberrations}

Results were analyzed separately for each eye and compared. There were no statistically significant differences between aberrations of right and left eyes. Thus, for the remaining statistical tests, data for only the right eyes were used.

\section{Refractive data}

The median spherical refraction was $+1.00 \mathrm{SD}$ in children and $+0.50 \mathrm{SD}$ in adults and increased in middle aged adults. All patients presented equal to or less than $1.75 \mathrm{CD}$. No tendency towards against the rule astigmatism was found in this sample.

\section{Ocular, corneal and lens aberrations}

The total ocular aberrations (low plus high-order aberrations) increased but not significantly with age $(\mathrm{p}=0.27)$. Median values were $3.83 \mu \mathrm{m}$ in children; $6.26 \mu \mathrm{m}$ in young adults; $5.47 \mu \mathrm{m}$ in adult and $5.45 \mu \mathrm{m}$ in middle aged adults (Figure 1).

High-order ocular aberrations increased significantly with age $(\mathrm{p}<0.0001)$. This tendency was most evident in middle aged adults (Figure 2). Spearman's coefficient was 0.33. Highorder corneal aberrations did not increase with age. However, high-order lens aberrations increased significantly, mainly in groups with more than 40 year-old $(\mathrm{p}<0.0001$, Figure 2$)$.

Figure 3 shows vertical coma analysis revealing a median of $0.10 \mu \mathrm{m}$ in children and $-0.07 \mu \mathrm{m}$ in middle aged adults. Values became negative with age $(\mathrm{p}<0.0001)$. 


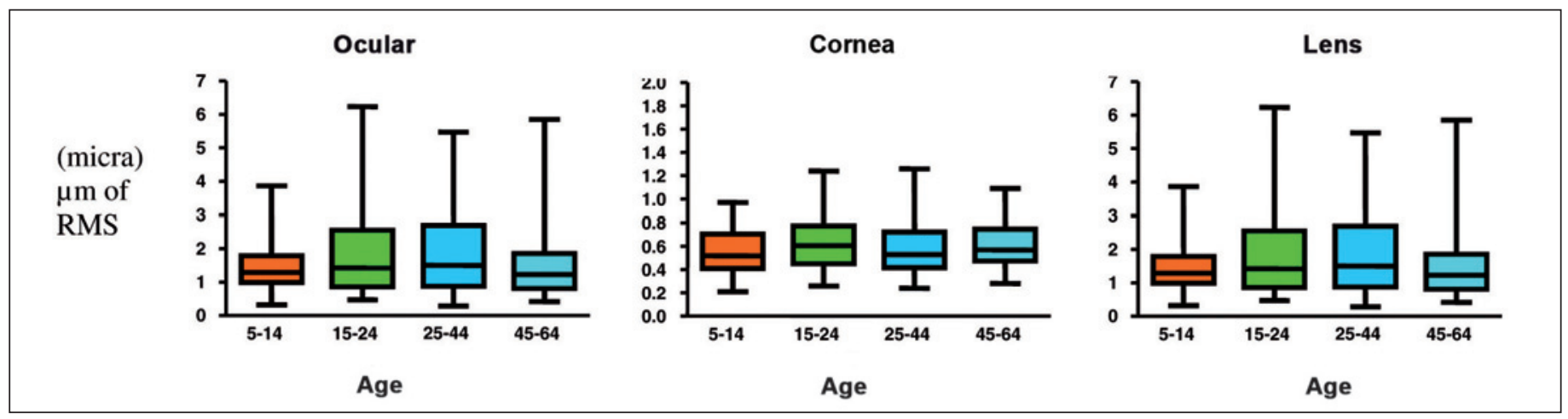

Figure 1 - Total aberrations (in $\mu \mathrm{m}$ ) in whole eye (ocular), cornea and lens by age

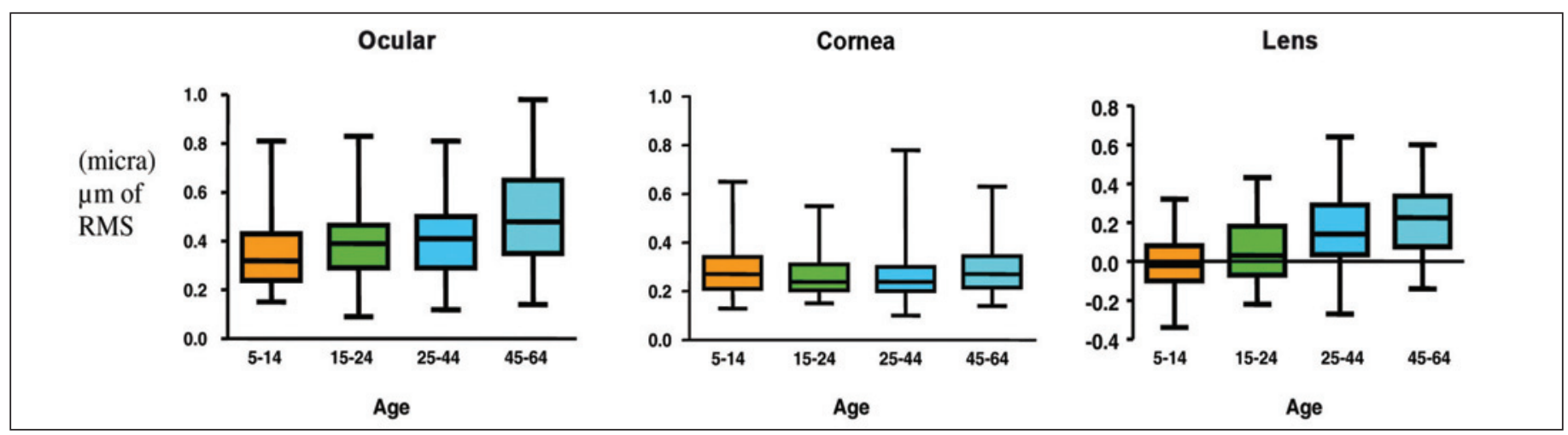

Figure 2 - High order aberrations (in $\mu \mathrm{m}$ ) in whole eye (ocular), cornea and lens by age

Changes in vertical ocular coma were more significant in subjects over 24 year-old $(\mathrm{p}<0.001)$ and this aberration was moderately correlated with age $(\mathrm{r}=-0.35)$.

Vertical corneal coma did not change with age $(\mathrm{p}=0.13)$. Vertical lens coma seems negative with age $(\mathrm{p}=0.0003)$.

Values of horizontal ocular and lens coma were similar to those for vertical ocular and lens coma. Median horizontal ocular coma was $0.01 \mu \mathrm{m}$ in children and $-0.12 \mu \mathrm{m}$ in middle aged adults. Horizontal corneal coma did not change with age $(\mathrm{p}=0.51)$. Horizontal lens coma changed significantly with age $(\mathrm{p}=0.0005)$.

Ocular spherical aberrations increased with age $(\mathrm{p}<0.001)$. Values began negative in children and became positive with aging $(\mathrm{p}<0.0001)$ (Figure 4). Median ocular spherical aberration was $0.02 \mu \mathrm{m}$ in children and $0.26 \mu \mathrm{m}$ in middle aged adults (Figure 4). Spearman's coefficient was 0.45.

Corneal spherical aberrations did not change with age $(p=0.49)$. Lens spherical aberrations significantly increased with age $(\mathrm{p}<0.0001)$ with a median of $-0.01 \mu \mathrm{m}$ in children and $0.22 \mu \mathrm{m}$ in middle aged adults.

\section{DISCUSSION}

Aging induces optical aberrations thus limiting the ability to see because of the degradation of the retinal image qua- lity ${ }^{(4-5)}$. So it is important to know the aberration behavior across the ages. In the present study, ocular and corneal aberrations were calculated and analyzed, and lens aberrations were indirectly determined by subtracting the last aberration values from the former.

As previously reported, there were no significant differences between aberrations of the right and left eyes ${ }^{(6)}$. For this reason, only right eyes aberrations values were presented to avoid the influence of the interdependence between eyes from the same subject.

Total ocular aberrations did not change with age, but ocular and lens high-order aberrations increased. Corneal aberrations did not change with age, the Spearman's coefficient was 0.33 , similar to reported by some authors ${ }^{(6-7)}$. Study reported an increase of high-order aberrations in children, which decreased in middle age, and increased again in the elderly. Despite their use of the same inclusion criteria as in the present study, they studied subjects using accommodative states different from the used in the current study and probably this explained increased aberrations in early ages, since lens accommodation induces aberration ${ }^{(7)}$.

Spherical aberration affects visual quality ${ }^{(8-9)}$. In accommodating eyes, it is positive and in non-accommodating eyes, the spherical aberration is negative. In the present study, ocular spherical aberration was negative in children and increased towards a positive value mainly in subjects older 


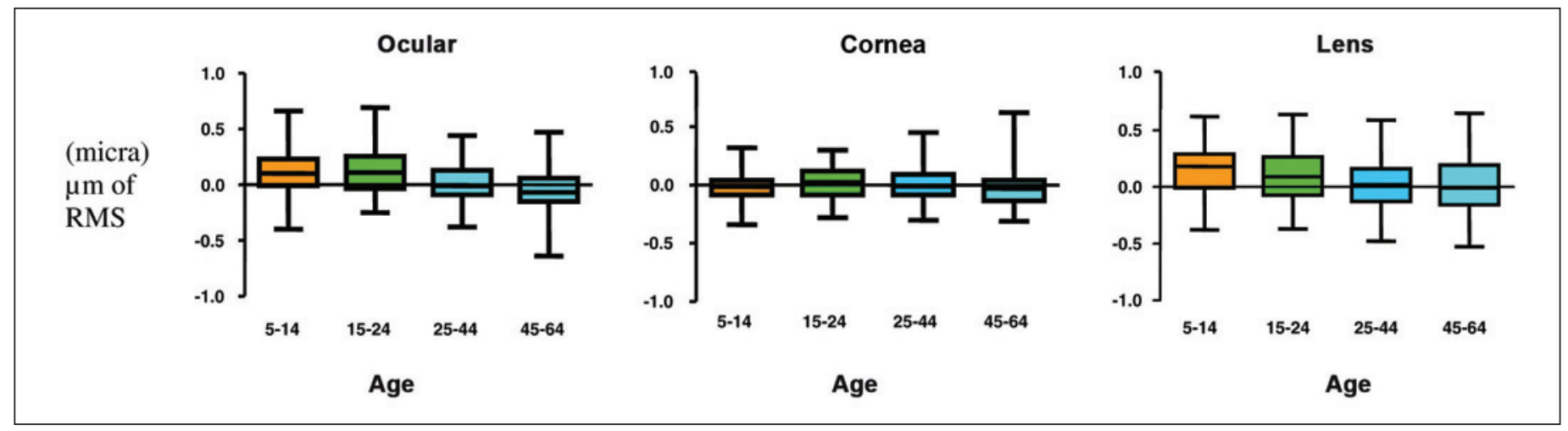

Figure 3 - Vertical coma (in $\mu \mathrm{m}$ ) the whole eye, cornea and lens by age

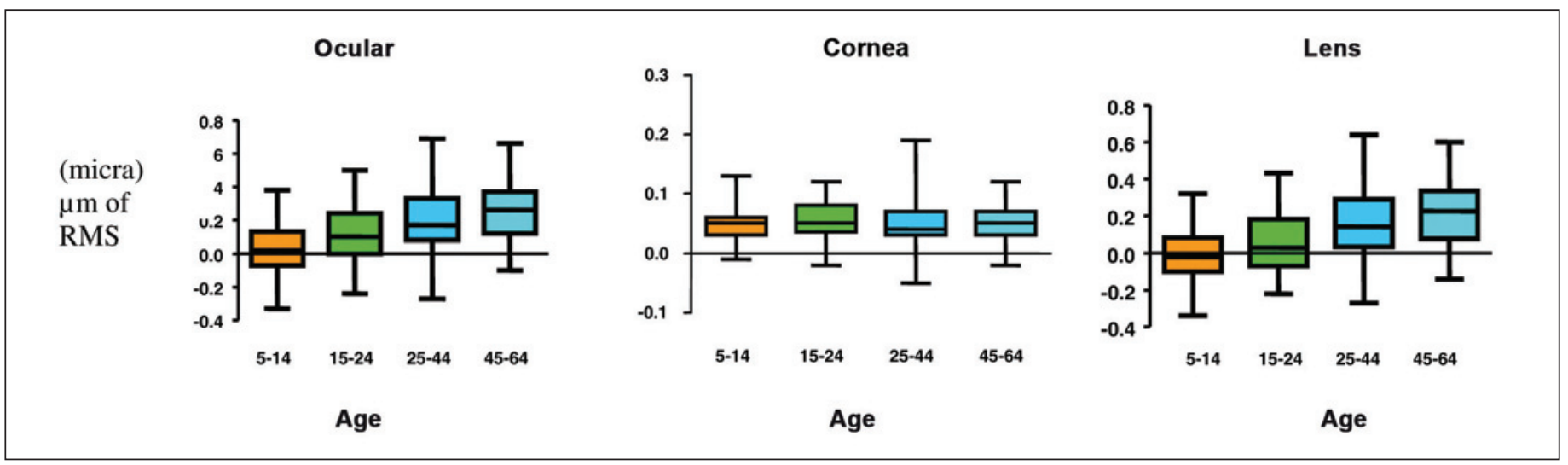

Figure 4 - Spherical aberration (in $\mu \mathrm{m}$ ) in whole eye, cornea and lens

than 45 year-old. This is probably due to changes in the lens that occur after 40 year-old ${ }^{(10)}$ such as the decreased lens refraction index, decreased ocular surface asphericity, and the increased lens thickness ${ }^{(11-13)}$. Lens thickness increases $0.02 \mu \mathrm{m} /$ year, mostly in the lens center ${ }^{(10)}$.

In this study, corneal spherical aberration did not change and was positive in all groups, as reported by some authors ${ }^{(14-15)}$. Others reported negative corneal spherical aberration in the elderly $^{(16)}$.

Studies show negative spherical aberration in children, values near zero at about 30 year-old, and positive values after this age ${ }^{(17-18)}$. This study, spherical aberration values were zero in young adults (15-24 year-old). In children, spherical aberrations were negative in $50 \%$ of the cases. It was reported a rate of $85 \%$ in children ${ }^{(9)}$. This difference is probably due to differences in lens accommodation between studies. As known, accommodation levels influence spherical aberration measurements $^{(19)}$.

Children had less spherical aberrations than elderly due to compensation between cornea and lens. Lens spherical aberration is negative and corneal spherical aberrations is positive in children. This mechanism is lost in older ages. Spearman's coefficient for spherical aberration was 0.45 and this value was slightly higher than that reported by some authors $(r=0.38)^{(10,20)}$. We consider this to be a moderate correlation with age.
Vertical, horizontal and lens coma became negative with age. Vertical coma tends to become negative with age, probably due to age-related changes in the cornea. In younger ages, vertical lens coma was positive and greater than vertical corneal coma. In older age-groups, ocular and corneal vertical comas were negative. The correlation was -0.45 , which was reported previously ${ }^{(10,21)}$. It occurs probably due to changes in the cornea caused by less eyelid tension ${ }^{(22-23)}$. In children, the main factor influencing horizontal ocular coma was the cornea and in older ages the main factor was the lens.

Study reported a compensatory factor between corneal and lens coma. In the present study, corneal aberrations appeared to compensate for vertical coma in early ages but was unable to compensate for vertical coma in the older age$\operatorname{groups}^{(5,24)}$.

Despite methodological differences in published studies, the consistent conclusion of the majority of them is that the cornea did not explain the increased aberrations but the aging lens changes can do it.

\section{CONCLUSIONS}

High-order ocular spherical aberrations increased and were moderately correlated with age. Vertical and horizontal ocular 
coma values were moderately and negatively correlated with age. Corneal aberrations did not change significantly. Aberrations increased in the eyes probably due to lens changes with age.

\section{RESUMO}

Introdução: A idade afeta o sistema visual. A qualidade da visão se deteriora progressivamente com a idade, a sensibilidade ao contraste diminui e as aberrações oculares aumentam contribuindo para a piora da qualidade visual. Objetivo: Estudar prospectivamente as aberrações oculares entre as idades de 5 a 64 anos. Métodos: Foram examinados 315 pacientes, 155 homens $(39,36 \%)$ e 160 mulheres $(60,63 \%)$ com idades entre 5 a 64 anos. O estudo foi realizado entre fevereiro a novembro de 2004. Os pacientes foram divididos em quatro grupos etários de acordo com a classificação do IBGE (Instituto Brasileiro de Geografia e Estatística): 68 pacientes entre 5 a 14 anos, 55 pacientes entre 15 a 24 anos, 116 pacientes entre 25 a 44 anos e 76 pacientes entre 45 a 67 anos de idade. Todos apresentavam acuidade visual corrigida para longe $\geq 20 / 25$, emetropia ou equivalente esférico $\leq 3,5 \mathrm{DE}$, astigmatismo $\leq 1,75 \mathrm{DC}$ ao exame sob cicloplegia, exame oftalmológico normal e sem cirurgia oftalmológica prévia. O Comitê de Ética da Universidade Federal de São Paulo aprovou esse protocolo. As aberrações foram medidas usando o sensor H-S (Hartmann-Shack) LadarWave ${ }^{\circledR}$ (Alcon Laboratories Inc, Orlando, FL, USA) e foram analisados estatisticamente. As aberrações da córnea foram calculadas usando o programa CT-View Versão 6.89 (Sarver and Associates, Celebration, FL, USA). As aberrações do cristalino foram calculadas por subtração. Resultados: Encontramos um aumento das aberrações de alta ordem $(0,32$ e $0,48 \mu \mathrm{m})$ e da aberração esférica do olho $(0,02$ e $0,26 \mu \mathrm{m})$ respectivamente nas faixas etárias correspondentes às crianças e meia-idade. As aberrações de alta ordem $(0,27 \mu \mathrm{m})$ e a aberração esférica da córnea $(0,05 \mu \mathrm{m})$ não se modificaram com a idade. A aberração esférica do cristalino aumentou (de 0,02 a 0,22 $\mu \mathrm{m}$ ). O coma vertical e horizontal apresentaram valores negativos progressivamente com a idade. Conclusão: As aberrações de alta ordem e a aberração esférica do olho aumentaram com a idade. As aberrações da córnea não aumentaram significativamente. As alterações que ocorrem no cristalino com a idade parecem ser responsáveis pelo aumento das aberrações do olho em idades mais avançadas.

Descritores: Fenômenos fisiológicos oculares; Topografia da córnea; Envelhecimento/fisiologia; Erros de refração/fisiopato- logia; Refração ocular/fisiologia; Técnicas de diagnóstico oftalmológico; Acuidade visual/fisiologia; Cristalino/fisiologia

\section{REFERENCES}

1. Guirao A, González C, Redondo M, Geraghty E, Norrby S, Artal P. Average optical performance of the human eye as a function of age in a normal population. Invest Ophthalmol Vis Sci. 1999;40(1):203-13.

2. Shahidi M, Yang Y. Measurements of ocular aberrations and light scatter in healthy subjects. Optom Vis Sci. 2004;81(11):853-7.

3. Schor P, Beer SM, Silva O, Takahashi R, Campos M. A clinical follow up of PRK and LASIK in eys with preoperative abnormal corneal topographies. Br J Ophthalmol. 2003;87(6):682-5.

4. Simonet P. Influence of ametropia of the optical of the human eye. Invest Ophthalmol Vis Sci. 1999;40:s448.

5. Artal P, Guirao A, Berrio E, Williams DR. Compensation of corneal aberrations by the internal optics in the human eye. J Vis. 2001;1(1):1-8.

6. Porter J, Guirao A, Cox IG, Williams DR. Monochromatic aberrations of the human eye in a large population. J Opt Soc Am A Opt Image Sci Vis. 2001; 18(8):1793-803.

7. Brunette I, Bueno JM, Parent M, Hamam H, Simonet P. Monochromatic aberrations as a function of age, from childhood to advanced age. Invest Ophthalmol Vis Sci. 2003;44(12):5438-46.

8. Tomlinson A, Hemenger RP, Garriott R. Method for estimating the spheric aberration of the human lens in vivo. Invest Ophthalmol Vis Sci. 1993;43(3):621-9.

9. Kirwan C, O'Keefe M, Soeldner H. High order aberrations in children. Am J Ophthalmol. 2006;141(1):67-70.

10. Alio JL, Schimchak P, Negri HP, Montés-Micó R. Crystalline lens optical dysfunction through aging. Ophthalmology. 2005;112(11):2022-9. Comment in: Ophthalmology. 2007;14(3):618; author reply 619.

11. Sivak JG, Kreuzer RO. Spherical aberration of the crystalline lens. Vision Res. 1983;23(1):59-70.

12. Millodot M, Sivak J. Contribution of the cornea and lens to the spherical aberration of the eye. Vision Res. 1979;19(6):685-7.

13. Glasser A, Croft MA, Kaufman PL. Aging of the human crystalline lens and presbyopia. Int Ophthalmol Clin. 2001;41(2):1-15.

14. Amano S, Amano Y, Yamagami S, Miyai T, Miyata K, Samejima T, et al. Age-related changes in corneal and ocular higher-order wavefront aberrations. Am J Ophthalmol. 2004;137(6):988-92. Comment in: Am J Ophthalmol. 2004;138(5):897; author reply 897.

15. Fujikado T, Kuroda T, Ninomiya S, Maeda N, Tano Y, Oshika T, et al. Agerelated changes in ocular and corneal aberrations. Am J Ophthalmol. 2004; 138(1):143-6.

16. Guirao A, Redondo M, Artal P. Optical aberrations of the human cornea as a function of age. J Opt Soc Am A Opt Image Sci Vis. 2000;17(10):1697-702.

17. Cook CA, Koretz JF, Pfahnl A, Hyun J, Kaufman PL. Aging of the human crystalline lens ans anterior segment. Vision Res 1994;34(22):2945-54.

18. Glasser A, Campbell MC. Biometric, optical and physical changes in the isolated human crystalline lens with age in relation to presbyopia. Vision Res. 1999;39(11):1991-2015.

19. Collins MJ, Wildsoet CF,Atchison DA. Monochromatic aberrations and myopia. Vision Res. 1995;35(9):1157-63.

20. Wang 1, Koch DD. Ocular higher-order aberrations in individuals screened for refractive surgery. J Cataract Refract Surg. 2003;29(10):1896-903.

21. Salmon TO, van de Pol C. Normal-eye Zernike coefficients and root-meansquare wavefront errors. J Cataract Refract Surg. 2006;32(12):2064-74.

22. Buehren T, Collins MJ, Iskander DR, Davis B, Lingelbach B. The stability of corneal topography in the post-blink interval. Cornea. 2001;20(8):826-33.

23. Han W, Kwan W, Wang J, Yip SP, Yap M. Influence of eyelid position on wavefront aberrations. Ophthalmic Physiol Opt. 2007;27(1):66-75.

24. Artal P, Berrio E, Guirao A, Piers P. Contribution of the cornea and internal surfaces to the change of ocular aberrations with age. J Opt Soc Am A Opt Image Sci Vis. 2002;19(1):137-43. 